\title{
PEMBEBANAN HAK TANGGUNGAN TERHADAP SATUAN KODOMINIUM HOTEL (KONDOTEL)
}

\author{
Dr. Desak Putu Dewi Kasih, SH.,M.Hum. \\ Ni Putu Purwanti, SH.,M.Hum. \\ Fakultas Hukum, Universitas Udayana, Denpasar \\ E-mail:dewiksh@ymail.com
}

\begin{abstract}
ABSTRAK
Kondotel merupakan apartemen non hunian yang dikelola dengan managemen hotel lahirnya konsep kondotel sebagai sarana penunjang pariwisata disebabkan kareana keterbatasan lahan-lahan strategis/lokasi yang strategis sedangkan kebutuhan akan sarana penunjang pariwisata semakin meningkat. Keterbatasan lahan ini juga menyebabkan meningkatnya harga tanah pada daerah-daerah tujuan wisata, sehingga para investor berupaya dalam mengembangkan kebutuhan sarana pariwisata dengan membangun apartemen non hunian dengan managemen hotel atau kondotel. Di Indonesia kondotel mulai berkembang lima tahun belakangan ini, dimana produk properti ini muncul sebagai salah satu strategi pengembang untuk mencari alternatif pembangunan akibat keterbatasan lahan untuk pembangunan sarana pariwisata disamping karena tingginya harga tanah di daerah-daerah pariwisata. Dewasa ini konsep penginapan (hotel) bagi wisatawan telah mengalami pergeseran bentuk dan model pengelolaan dari yang bersifat konvensional menjadi bersifat modern akibat pertumbuhan ekonomi yang sangat pesat salah satunya adalah model pengelolaan kondominium hotel. Pengaturan kondominium hotel sebagai obyek hak tanggungan dalam perjanjian kredit bank dapat diklasifikasikan kedalam tiga stuktur norma pengaturan yang terdiri dari: a) Norma pengaturan yang bersifat umum, yang mendasarkan pengaturan pada ketentuan-ketentuan hukum peraturan perundang-undangan terkait dengan perbankan, pengadaan rumah susun dan hak tanggungan;b) Norma pengaturan yang bersifat khusus yang meliputi ketentuan prinsip kehati-hatian dalam pemberian kredit, ketentuan mengenai analisa mendalam terhadap karakter, kapital, kolateral dan kapasitas debitur serta ketentuan batas maksimum pemberian kredit dari bank selaku kreditur; c) Norma pengaturan konstruktif berupa model kontrak yang disepakati oleh pihak-pihak dalam pemberian kredit dengan obyek kondominium hotel melalui hak tanggungan, yang berlaku sebagai undang-undang bagi para pihak yang membuatnya. Perlindungan hukum terhadap pemilik satuan kondominium hotel apabila terjadi wan prestasi dalam perjanjian kredit bank adalah dengan mengupayakan prinsip itikad baik (good faith) baik pada awal perjanjian, pelaksanaan perjanjian hingga berakhirnya perjanjian dengan menegaskan pada substansi perjanjian tentang konstruksi hukum kondominium hotel dengan adanya karakteristik yang melekat pada kondominium hotel yaitu adanya tanah bersama dan benda bersama.
\end{abstract}

Kata kunci: hak tanggungan, kondominium hotel

\section{A. LATAR BELAKANG MASALAH}

Bisnis jasa pariwisata merupakan salah satu andalan penggerak pertumbuhan ekonomi. Bali merupakan salah satu tujuan wisata andalan yang telah mengalami peningkatan kualitas pariwisata di Indonesia. Peningkatan kualitas pariwisata akan memberikan dampak positif bagi negara, masyarakat maupun pelaku usaha di bidang kepariwisataan. Kepariwisataan menurut Hans.Buchli adalah setiap peralihan tempat yang bersifat sementara dari seseorang atau beberapa orang, dengan maksud memperoleh pelayanan yang diperuntukkan bagi kepariwisataan itu oleh lembaga-lembaga yang digunakan untuk maksud tertentu ${ }^{1}$

${ }^{1}$ http://id.wikipedia.org/wiki/pariwisata
Menurut ketentuan Undang-Undang No. 10 Tahun 2009 Tentang Kepariwisataan disebutkan bahwa pariwisata adalah berbagai kegiatan wisata dan didukung berbagai fasilitas serta layanan yang disediakan oleh masyaraka, pengusaha dan Pemerintah. ${ }^{2}$ Dalam ketentuan Pasal 7 disebutkan bahwa pembangunan kepariwisataan meliputi : industri pariwisata, destinasi pariwisata, pemasaran dan kelembagaan kepariwisataan. Guna menunjang kegiatan kepariwisataan maka dibutuhkan sarana dan prasarana kepariwisataan yang perlu dipersiapkan guna menunjang industri

2 Pasal 1 angka 4 Undang-Undang No. 10 Tahun 2009 Tentang Kepariwisataan 
pariwisata sebagai salah satu sektor kegiatan perekonomian.

Penyediaan sarana kepariwisataan sangat dibutuhkan oleh wisatawan baik berupa sarana pokok, sarana pelengkap maupun sarana penunjang $^{3}$ demikian pula halnya dengan penyediaan prasarana yang memungkinkan wisatawan mengunjungi suatu daerah dan pelayanan yang diberikan belum memadai. Investasi dibidang kepariwisataan dapat dilakukan dalam bentuk keterlibatan pemerintah, masyarakat dan investasi (pengusaha) dalam mengupayakan peningkatan sarana dan prasarana kepariwisataan seperti penginapan (hotel), kawasan wisata (obyek dan daya tarik wisata) serta sumber daya manusia.

Dewasa ini konsep penginapan (hotel) sebagai akomodasi bagi wisatawan telah mengalami pergeseran bentuk dan model pengelolaan dari yang bersifat konvensional menjadi bersifat modern akibat pertumbuhan ekonomi yang sangat pesat salah satunya adalah model pengelolaan kondominium hotel. Bentuk investasi demikian telah mengalami perkembangan di setiap daerah yang menjadi tujuan wisata seperti halnya di Bali. Di Bali pengelolaan kondominium hotel dilakukan dengan cara kerjasama investasi antara pengelola dengan investor sebagai pemilik satuan-satuan kondominium hotel (selanjutnya disebut kondotel). Akibat perkembangan kepariwisataan yang semakin kompleks dan peningkatan akan kebutuhan sarana dan prasarana yang semakin bertambah akibat pertumbuhan angka kunjungan yang semakin meningkat namun disisi lain lahan yang tersedia sudah tidak memadai untuk pembangunan hotel disamping juga karena model pengelolaan kondotel sebagai model pengelolaan hotel dengan konsep investasi merupakan perkembangan baru dari kegiatan kepariwisataan, sehingga masih membutuhkan pengkajian mendalam dan sangatlah penting untuk dibahas lebih lanjut mengenai perjanjian kerja sama pengelolaan kondotel. Adapun rumusan masalah yang akan dikaji adalah pengaturan investasi dan konstruksi normatif perjanjian kerjasama pengelolaan kondotel.

\section{B. METODE PENELITIAN}

Penelitian ini merupakan penelitian hukum normatif yang bertujuan untuk mengidentifikasi norma-norma dalam perjanjian kerjasama pengelolaan kondominium hotel (kondotel) guna merumuskan konstruksi normatif darikondotel sebagai obyek hak tanggungan. Adapun pendekatan yang dipergunakan dalam penelitian ini adalah pendekatan analisa konsep hukum (analitical and conceptual approach) dilakukan dengan penelaahan secara mendalam tentang

${ }^{3}$ Parikesit D. dan Trisandi,1997, Kebijakan Kepariwisataan Indonesia Dalam Pembangunan Jangka Panjang, Jogyakarta, Gajahmada University Business Review No. 16/VI hal.67 permasalaan yang ada berdasarkan konsepkonsep, teori-teori dan asas-asas dalam perjanjian kerjasama investasi serta pendekatan perundang-undangan (statute approach) terhadap peraturan perundang-undangan yang berlaku dalam kegiatan perbankan dan transaksi pertanahan khususnya kondotel.

Lebih lanjut bahan hukum yang dikaji meliputi bahan hukum primer, bahan hukum sekunder dan bahan hukum tersier terhadap peraturan perundang-undangan dan terhadap dokumen perjanjian yang relevan untuk selanjutnya dianalisis dengan mengidentifikasi kualitas bahan hukum dan penerapan teknik penemuan hukum dengan metode interpretasi.

\section{HASIL DAN PEMBAHASAN}

\section{Pengaturan Investasi Dalam Bidang Kondotel}

Mochtar Kusumaatmadja dalam Lilik Mulyadi ${ }^{4}$ berpendapat bahwa tujuan pokok hukum bila direduksi pada satu hal saja adalah ketertiban yang dijadikan syarat pokok bagi adanya masyarakat yang teratur. Tujuan lain hukum adalah tercapainya keadilan yang berbeda-beda isi dan ukurannya, menurut masyarakat dan jamannya. Selanjutnya untuk mencapai ketertiban diusahakan adanya kepastian hukum dalam pergaulan manusia di masyarakat, karena tidak mungkin manusia dapat mengembangkan bakat dan kemampuan yang diberikan Tuhan kepadanya secara optimal tanpa adanya kepastian hukum dan ketertiban. ${ }^{5}$ Lebih lanjut disebutkan bahwa fungsi dari peraturan hukum sebagai alat pengatur atau sarana pembangunan bertujuan agar tercapai ketertiban dan kepastian sebab segala kegiatan pemerintah berlandaskan hukum dan undangundang. Oleh karena itu pembentukan dan pembaharuan undang-undang yang mengatur rumah susun mutlak diperlukan agar tercapai tujuan hukum baik keadilan, kemanfaatan maupun kepastian hukum. Pemerintah terus melakukan pembaharuan pengaturan hukum rumah susun, mengingat kebutuhan rumah susun sebagai salah satu alternatif hunian dan pesatnya pembangunan rumah susun, perlu mendapat payung hukum yang kuat.

Meningkatnya eksistensi bisnis properti dan kecenderungan mengembangkan bangunan vertikal seperti halnya rumah susun atau apartemen menjadi solusi dibeberapa wilayah yang mengalami keterbatasan lahan dikarenakan meningkatnya jumlah penduduk atau populasi. Pembangunan perumahan atau hunian berbentuk rumah susun atau apartemen dapat mengurangi 
penggunaan tanah dan membuat ruang terbuka lebih lega merupakan salah satu alternatif. ${ }^{6}$

Undang-Undang Nomor 20 Tahun 2011 tentang Rumah Susun (selanjutnya disebut UU Rumah Susun) menetapkan empat jenis rumah susun, yaitu: a)Rumah Susun Umum ${ }^{7}$ adalah rumah susun yang diselenggarakan untuk memenuhi kebutuhan rumah bagi masyarakat berpenghasilan rendah; b) Rumah Susun Khusus $^{8}$ yang diselenggarakan untuk memenuhi kebutuhan khusus; c) Rumah Susun Negara ${ }^{9}$ adalah rumah susun yang dimiliki oleh Negara dan berfungsi sebagai tempat tinggal atau hunian, sarana pembinaan keluarga, serta penunjang pelaksanaan tugas pejabat dan/atau pegawai negeri dan Rumah Susun Komersial $^{10}$ adalah Rumah Susun yang diselenggarakan untuk mendapatkan keuntungan. Rumah susun dapat dibangun diatas tanah: hak milik, hak guna bangunan atas tanah Negara, hak guna bangunan atas hak pengelolaan, hak pakai atas tanah Negara dan hak pakai atas hak pengelolaan.

Terdapat dua macam sertifikat yang berkaitan dengan rumah susun, yaitu: a) Sertifikat Hak Milik Atas Satuan Rumah Susun (SHM Sarusun) yaitu tanda bukti kepemilikan atas satuan rumah susun diatas tanah hak milik, hak guna bangunan atau hak pakai atas tanah Negara serta hak guna bangunan atau hak pakai atas tanah hak pengelolaan dan b). Sertifikat Kepemilikan Bangunan Gedung (SKBG) Satuan Rumah Susun adalah tanda bukti kepemilikan Satuan Rumah Susun diatas barang milik Negara/daerah berupa tanah atau tanah wakaf dengan cara sewa.

Penguasaan hak milik atas Satuan Rumah Susun oleh pemiliknya tidak selalu untuk selama-lamanya, tetapi bergantung pada status hak atas tanahnya yaitu: a) Rumah Susun yang dibangun di atas tanah hak milik, maka penguasaan hak milik atas Satuan Rumah Susun oleh pemiliknya tidak dibatasi oleh jangka waktu karena sifat dari hak milik adalah turun temurun; b) Pembangunan Rumah susun diatas tanah Hak Guna Bangunan atas tanah negara atau Hak Guna Bangunan atas tanah Hak Pengelolaan, maka penguasaan atas rumah susun berjangka waktu untuk pertama kali paling lama 30 tahun dapat diperpanjang 20 tahun dan dapat diperbaharui haknya untuk jangka waktu paling lama 30 tahun dan c) Untuk Rumah Susun dibangun diatas tanah Hak Pakai atas tanah negara atau hak pakai atas tanah hak pengelolaan, maka penguasaan hak miliknya

6 Urip Santoso, 2010, Pendaftaran dan

Peralihan Hak Atas Tanah, Kencana Persada, Media, Jakarta, h.77

${ }^{7}$ Undang-Undang Nomor 20 Tahun 2011

Tentang Rumah Susun, Pasal 1 angka 7

${ }^{8}$ Ibid, Pasal 1 angka 8

${ }^{9}$ Ibid, Pasal 1 angka 9

${ }^{10}$ Ibid, Pasal 1 angka 10 berjangka waktu untuk pertama kalinya paling lama 25 tahun, dapat diperpanjang untuk jangka waktu paling lama 20 tahun dan dapat diperbaharui haknya untuk jangka waktu paling lama 25 tahun.

Dengan merujuk pada konsep kepemilikan atas hunian yang dibangun secara vertikal baik itu condominium, apartemen atau rumah susun maka konstruksi hukum penguasaan satuan unitunitnya berlaku ketentuan bahwa: a). Jika Rumah Susun dibangun diatas hak milik, maka rumah susun tersebut hanya dapat dimiliki oleh warga negara Indonesia atau badan hukum Indonesia yang ditetapkan oleh Pemerintah Indonesia; b). Jika Rumah Susun dibangun diatas Hak Guna Bangunan, maka rumah susun dapat dimiliki oleh warga Negara Indonesia dan badan hukum Indonesia yang berdomisili di Indonesia dan c). Jika dibangun diatas Hak Pakai, maka hak tersebut dapat dimiliki oleh: Warga Negara Indonesia, Warga Negara Asing, badan hukum Indonesia dan badan hukum asing yang memiliki perwakilan di Indonesia.

Pembangunan kondotel pada dasarnya merupakan perluasan konsep dari pembangunan rumah susun. Dengan demikian pengaturan tentang kondotel masih mengacu pada ketentuan-ketentuan yang mengatur tentang rumah susun menurut ketentuan pasal 1 angka 1 UU Rumah Susun bahwa : Rumah Susun adalah bangunan gedung bertingkat yang dibangun dalam suatu lingkungan yang terbagi dalam bagian-bagian yang distrukturkan secara fungsional, baik dalam arah horizontal maupun vertikal dan merupakan satuan-satuan yang masing-masing dapat dimiliki dan digunakan secara terpisah, terutama untuk tempat hunian yang dilengkapi dengan bagian bersama, benda bersama dan tanah bersama. ${ }^{11}$ Atas dasar pengertian tersebut maka dapat dimaknai bahwa rumah susun merupakan bangunan bertingkat yang dihuni bersama dan merupakan satuan yang dapat dimiliki secara terpisah. Ada beberapa jenis rumah susun yang dikenal di Indonesia yaitu : Rumah susun, apartemen, Kondominium yang ketiganya termasukdalam tipe flat, town house (pembangunan secara vertikal), yang pada dasarnya memiliki fungsi yang sama ${ }^{12}$

Dalam perkembangannya rumah susun dapat diklasifikasikan menjadi 3 (tiga) yaitu rumah susun sederhana (Rusuna), Rumah Susun Menengah (Apartemen) dan Rumah Susun Mewah (Kondominium). Kondominium menunjuk pada suatu bentuk pemilikan yang melibatkan lebih dari seorang Pemilik

${ }^{11}$ Pasal 1 angka 1 Undang-undang Nomor 20 tahun 2011 tentang Rumah Susun (UU Rumah Susun)

12 Suriansyah Murhaini, 2015, Hukum Rumah Susun, Eksistensi, Karakteristik dan Pengaturan, Laksbang Grafika, h.5 
Bangunan $^{13}$. Keberadaan Kondominium Hotel merupakan pengembangan peruntukan dari sebuah kondominium dalam rangka perkembangan industri pariwisata karena investasi di sektor kondominium hotel (Kondotel) dianggap menjadi salah satu investasi yang menguntungkan terlebih-lebih didaerah-daerah yang menjadi tujuan berlibur para wisatawan domestik maupun mancanegara. Ada beberapa faktor yang menjadikan kondotel sangat diminati oleh investor antara lain : masyarakat menengah keatas masih percaya bahwa bisnis properti adalah instrument investasi yang paling aman, masyarakat yakin prospek investasi properti masih sangat baik di daerah tujuan wisata bagi daerah tujuan yang memiliki keterbatasan lahan dan memiliki pesona yang dapat menarik kunjungan wisatawan. Kondotel sebagai produk investasi properti menawarkan model kepemilikan terhadap unit kondominium dengan keuntungan dari nilai sewa unit yang secara rutin diterima.

Dalam Kitab Undang-Undang Hukum Perdata Pasal 570 tentang Hak Milik, bahwa hak milik adalah hak untuk menikmati kegunaan sesuatu kebendaan dengan leluasa dan untuk berbuat bebas terhadap kebendaan itu dengan kedaulatan sepenuhnya, asal tidak bersalahan dengan undang-undang atau peraturan umum yang ditetapkan oleh sesuatu kekuasaan yang berhak menetapkannya dan tidak mengganggu hak-hak orang lain, kesemuanya itu dengan tak mengurangi kemungkinan akan pencabutan hak itu demi kepentingan umum berdasarkan atas undang-undang dan dengan pembayaran gati rugi. Hak milik tersebut bersifat mutlak tidak dapat diganggu gugat sedangkan menurut UUPA mengandung arti bahwa hak milik merupakan hak yang terkuat, jika dibandingkan dengan hak-hak atas tanah lainnya, seperti hak guna usaha, hak guna bangunan dan lain-lain. Dengan demikian Hak Milik adalah hak untuk menikmati suatu benda dengan sepenuhnya dan untuk menguasai benda itu dengan undangundang atau peraturan umum yang diadakan oleh kekuasaan yang mempunyai wewenang untuk itu asal tidak mengganggu hak orang lain, kesemuanya dengan tidak mengurangi kemungkinan akan pencabutan hak itu untuk kepentingan umum, dengan pembayaran pengganti kerugian yang layak dan menurut ketentuan undang-undang.

Konsep kondominium berasal dari konsep rumah susun merupakan hak guna perumahan dimana suatu bagian tertentu dimiliki secara ppribadi sementara penggunaan lain dan akses ke fasiliatas umumberada dibawah hukum yang dihubungkan dengan kepemilikan pribadi dan

${ }^{13}$ M. Rizal Arif, Analisis Kepemilikan Hak Atas Tanah Satuan Rumah susun Dalam Kerangka Hukum Benda, h.71 dikontrol oleh asosiasi pemilik ${ }^{14}$ sedangkan strata title merupakan suatu kepemilikan terhadap sebagian ruang dalam suatu gedung bertingkat seperti apartemen atau rumah susun dengan demikian pemegang hak milik satuan rumah susun berhak atas bagian bersama, benda-benda bersama dan tanah bersama dalam bentuk prosentase kepemilikan. Mengenai konsep kepemilikan bersama atas tanah, menurut Paul Stepen Latimer ${ }^{15}$, land means the solid parts of the earth's surface and includes houses, farm and bush. Land is permanent and its cannot be hidden or moved. It can be improved or degraded but cannot be destroyed. Land is opposite of sea, water and air. (tanah adalah bagian padat dari permukaan bumi dan termasukrumah peternakan dan semak. Tanah bersifat tetap atau tidak bergerak dan tidak dapat disembunyikan atau dipindahkan. Hal ini dapat ditingkatkan atau diturunkan tetapi tidak dapat dihancurkan. Tanah adalah kebalikan dari laut, air dan udara). Sistem kepemilikan atas bangunan atau gedung bertingkat dimungkinkan adanya kepemilikan atas bagian-bagian secara individual dalam bentuk hak milik atas satuan rumah susun sedangkan bagian-bagian lain menjadi milik bersama yang tidak terpisah dari semua pemilik satuan rumah susun yang masing-masing merupakan bagian yang tidak terpisahkan dari pemilikan satuan rumah susun yang bersangkutan.

Undang-Undang Nomor 5 Tahun 1960 tentang Peraturan Dasar Pokok-Pokok Agraria (UUPA) sebagai Instrumen yang mengatur tentang hak milik atas tanah dari pasal 20 sampai dengan pasal 27. Menurut ketentuan Pasal 20 ayat (1), bahwa hak milik adalah hak turun temurun, terkuat dan terpenuh yang dapat dipunyai. Sesuai ketentuan Pasal 21 ayat (1) dan ayat (2) UUPA, maka yang dapat mempunyai Hak Milik adalah Warga Negara Indonesia dan Badan-badan Hukum yang ditunjuk oleh pemerintah melalui Peraturan Pemerintah. Sedangkan Pasal 21 ayat (3) UUPA ditentukan bahwa Orang asing yang sesudah berlakunya undang-undang ini memperoleh Hak Milik, karena pewarisan tanpa wasiat atau percampuran harta karena perkawinan, demikian pula Warga Negara Indonesia yang kehilangan kewarganegaraannya wajib melepaskan hak itu. Apabila dalam jangka waktu satu tahun sejak diperolehnya hak tersebut atau hilangnya kewarganegaraan itu, Hak Milik tersebut tidak dilepaskan, maka hak tersebut hapus karena hukum, dengan ketentuan Hak-hak pihak lain yang membebaninya tetap berlangsung. Dengan yang berhak memiliki hak atas tanah dengan Hak Milik adalah hanya Warga Negara

14 Adrian Sutedi, 2007, Hukum Rumah Susun dan Apartemen, Sinar Grafika, Jakarta, h. 138

15 Paul Stepen Latimer, 2001, Australian Bussiness Law, CCH Australia Limited, h. 70 
Indonesia tunggal dan Badan Hukum yang ditunjuk oleh Pemerintah melalui peraturan pemerintah. Peraturan pemerintah dimaksud adalah Peraturan Pemerintah Nomor b 38 Tahun 1963 tentang Penunjukan Badan-badan Hukum yang Dapat Mempunyai Hak Milik atas Tanah yaitu : a) Bank-bank yang didirikan oleh Negara; b) Perkumpulan-perkumpulan Koperasi Pertanian yang didirikan berdansarkan atas Undang-undang Nomor 79 Tahun 1958; Badanbadan sosial yang ditunjuk oleh Menteri Pertanian/Agraria setelah mendengar Menteri Kesejahteraan Sosial.

Adapun unsur-unsur yang melekat dalam konsep kondominium hotel adalah sama dengan konsep rumah susun menurut Undang-Undang Nomor 20 Tahun 2011 Tentang Rumah Susun, bahwa rumah susun dari segi fisik merupakan bangunan yang berlantai lebih dari satu; dalam fungsinya dapat digunakan secara vertikal maupun horizontal; terdapat bagian yang dapat digunakan dan dimiliki secara terpisah oleh pemiliknya yang disebut satuan rumah susun (sarusun); terdapat hak bersama dari seluruh pemilik sarusun yang terdiri atas bagian bersama, benda bersama dan tanah bersama; tujuan utamanya adalah untuk tempat hunian atau rumah tinggal. Menurut Herman Hermit ${ }^{16}$, hak milik atas satuan rumah susun bukanlah macam hak atas tanah, melainkan hak milik atas fisik satuan rumah susun namun tetap merupakan obyek pendaftaran tanah yang wajib disertifikatkan. Sistem kepemilikan dalam bangunan bertingkat dalam hal ini ruimah susun dapat diklasifikasikan menjadi dua yaitu: pemilikan tunggal dan pemilikan bersama dimana dapat dilihat dari ada tidaknya ikatan hukum yang terlebih dahulu ada diantara pemilik gedung bertingkat antara lain pemilikan bersama yang terikat karena adanya ikatan hukum lebih dahulu antara pemilik dan pemilikan bersama yang bebas antara pemilik tidak ada hubungan hukum lebih dahulu selain hak bersama menjadi pemilik untuk digunakan bersama, hal demikian yang dikenal sebagai kondominium. ${ }^{17}$ Hubungan antara satuan-satuan kondominium dengan benda bersama, bagian bersama, dan tanah bersama tersebut dapat dilihat pada Nilai Perbandingan Proporsional (NPP). Yang dimaksud dengan NPP adalah nilai atau angka yang menunjukkan perbandingan antara satuan kodominium terhadap hak atas bagian bersama, benda bersama dan tanah bersama berdasarkan luas atau nilai satuan kondominium. NPP bukan hanya gambaran akan hak milik satuan kondominium terhadap hak atas tanah, benda dan bagian bersama tetapi

${ }^{16}$ Herman Hermit, 2004, Cara Memperoleh Sertifikat Tanah Hak Milik, Tanah Negara dan Tanah Pemda, Mandar Maju, Bandung, h.30

${ }^{17}$ Imam Kuswahyono, 2004, Hukum Rumah Susun, Bayu Media Publishing, Malang, h. 12 juga cerminan akan adanya kewajiban pemilik untuk mengeluarkan biaya pemeliharaan dan perbaikan kepemilikan bersama yang nantinya akan dibebankan padanya.

Menurut ketentuan Pasal 56 UU Rumah Susun bahwa pengelolaan rumah susun dalam hal ini kondominium hotel adalah meliputi kegiatan operasional, pemeliharaan dan perawatan bagian bersama, benda bersama dan tanah bersama. Pengelolaan sebagaimana dimaksud harus dilaksanakan oleh pengelola yang berbadan hukum kecuali rumah susun umum sewa, rumah susun khusus dan rumah susun negara. Badan hukum tersebut harus mendaftar dan mendapat izin usaha daru bupati/walikota dan khusus untuk Provinsi DKI Jakarta badan hukum tersebut harus mendaftar dan mendapat izin usaha dari Gubernur. Sebagaimana diketahui bahwa badan hukum menurut hukum Indonesia berbentuk perseroan terbatas yang diatur berdasarkan UndangUndang Nomor 40 Tahun 2007 Tentang Perseroan Terbatas (UUPT). Perseroan terbatas (Perseroan) adalah ${ }^{18}$ badan hukum yang merupakan persekutuan modal, didirikan berdasarkan perjanjian, melakukan kegiatan usaha dengan modal dasar yang seluruhnya terbagi dalam saham dan memenuhi persyaratan yang ditetapkan dalam undang-undang ini serta peraturan pelaksanaannya.

\section{Konstruksi Hukum Perjanjian Pengelolaan Kondotel}

Hubungan kontraktual pada umumnya diawali dengan proses negosiasi diantara para pihak yang berupaya menciptakan bentukbentuk kesepakatan untuk saling mempertemukan sesuatu yang diinginkan sebagai kepentingan para pihak yang bersepakat, sehingga melahirkan keterikan dan interaksi antar subyek-subyek hukum yang pada akhirnya menimbulkan hak dan kewajiban para pihak untuk dilaksanakan ${ }^{19}$

Menurut ketentuan Pasal 42 Undangundang Rumah Susun, bahwa pelaku pembangunan dapat melakukan pemasaran sebelum pembangunan rumah susun dilaksanakan, dalam hal demikian maka pelaku pembangunan (pengembang) sekurangkurangnya harus memiliki kepastian peruntukan ruang, kepastian ha katas tanah, kepastian status penguasaan rumah susun, perizinan pembangunan rumah susun, jaminan atas pembangunan rumah susun oleh lembaga penjamin sehingga segala sesuatu yang dijanjikan oleh pelaku pembangunan dan/atau

${ }^{18}$ Pasal 1 angka 1 Undang-undang Nomor 40 Tahun 2007 tentang Perseroan Terbatas.

${ }^{19}$ Eman Ramelan, dkk, 2015, Perlindungan Hukum Bagi Konsumen Pembeli Satuan Rumah Susun/Strata Title/Apartemen, Aswaja Pressindo, Yogyakarta, h.19 
agen pemasaran mengikat sebagai perjanjian pengikatan jual beli (PPJB) bagi para pihak. Selanjutnya proses jual beli dilakukan sesudah pembangunan rumah susun selesai dibangunyang dilakukan dengan akta jual beli (AJB) dengan memenuhi ketentuan Pasal 1320 KUHPerdata yaitu: sepakat yang mengikatkan diri, cakap dalam membuat suatu kontrak, mengenai hal tertentu dan suatu sebab yang halal. Dengan telah dipenuhinya syarat sahnya perjanjian tersebut maka perjanjian tersebut berlaku sebagai undang-undang bagi mereka yang membuatnya ${ }^{20}$

Alas hak kepemilikan mengandung konsekuensi hukum, ada legalitas pada jual beli jika subyek hukumnya sah sebagai pemilik hak dan jual beli dapat dilakukan melalui mekanisme yang disepakati dan ditetapkan oleh hukum, dimana prinsip utama peralihan melalui jual beli adalah adanya hak yang melekat bagi pemilik artinya seseorang memiliki kekuatan hukum sebagai pemilik.

Sesuai peruntukannya rumah susun dapat diklasifikasikan dalam beberapa jenis ${ }^{21}$ yaitu: a) Rumah Sejahtera Susun atau Rumah Susun Sederhana Milik adalah bangunan bertingkat yang dibangun disebidang lahan dan terbagi secara struktur horizontal dan vertikal. Bangunan terdiri atas satuan hunian yang dapat dimiliki dan digunakan secara terpisah, dilengkapi dengan fasilitas bersama berupa bagian, barang dan tanah bersama; b). Rumah Susun Sederhana Sewa (Rusunawa) adalah gedung bertingkat yang dibangun disebidang lahan dan terbagi secara struktur horizontal dan vertikal. Bangunan terdiri atas satuan-satuan hunian yang penguasaannya secara sewa dan dilengkapi dengan fasilitas bersama; c). Apartemen adalah bangunan bertingkat lebih dari satu lantai yang terdiri atas unit-unit hunian yang dibangun untuk disewakan. Bangunan apartemen ini mempunyai lobi koridor sirkulasi dan fasilitas bersama; d). Kondominium atau apartemen jual atau apartemen "strata title" merupakan bangunan bertingkat banyak diatas sebidang lahan dan terbagi secara struktur horizontal dan vertikal dimana setiap unit "strata title" dimiliki oleh masing-masing pembeli. Bangunannya dilengkapi dengan fasilitas bersama, termasuk tanah dimiliki secara proporsi sebagai Kepemilikan bersama; e). Kondominium Hotel (Kondotel) adalah kondominium yang dijual kepada investor terhadap setiap unit "strata title"nya kemudian dioperasikan (dikelola) sebagai hotel oleh operator hotel yang sudah ditunjuk oleh pengembang dengan ketentuan adanya pengembalian investasi (return On Investment atau ROI) untuk jangka waktu tertentu berdasarkan masa pengelolaan (operasional)

\footnotetext{
${ }^{20}$ Pasal 1338 Kitab Undang-undang Hukum Perdata

${ }^{21}$ Suriansyah Murhaini, Op.Cit, h. 35
}

serta pembagian keuntungan dari manajemen hotel setelah dikurangi biaya operasional dan f). Super Blok adalah suatu bangunan proyek multiguna yang terdiri dari perkantoran, hunian, hotel dan pusat perbelanjaan.

Pembebanan hak tanggungan merupakan langkah lanjutan dari perjanjian pinjam meminjam atau perjanjian kredit sebagaimana yang dikatakan oleh Mariam Darusbadrulzaman $^{22}$ yakni perjanjian kredit tersebut adalah "Perjanjian Pendahuluan" (Voorovereenkomst),sehingga tidak ada hak tanggungan tanpa perjanjian kredit. Pada umumnya yang melakukan kegiatan penyaluran dana ke masyarakat melalui kredit adalah bank. Bank merupakan salah satu lembaga yang memegang peranan penting dalam perekonomian nasional. Dari segi fungsinya, bank merupakan perantara antara kepentingan masyarakat dibidang dana, yaitu kepentingan dari masyarakat yang berkelebihan dana dengan kepentingan dari masyarakat yang membutuhkan dana. Bank menghimpun dana dari masyarakat luas dengan menyalurkan kembali kepada masyarakat melalui pemberian pinjaman atau kredit yang merupakan dua fungsi utama bank.

Dengan demikian kondotel yang akan dipergunakan sebagai jaminan kredit dalam pengikatannya dapat diklasfikasikan menjadi dua yaitu :

(a) Untuk kondominium hotel yang bukti kepemilikannya berupa Sertifikat Hak Milik Satuan Rumah Susun (SHM Sarusun) yaitu bagi yang di bangun diatas tanah hak milik, hak guna bangunan atau hak pakai diatas tanah negara dan hak guna bangunan atau hak pakai atas tanah hak pengelolaan dapat dibebani dengan hak tanggungan

(b) Untuk kondotel yang bukti kepemilikannya berupa Sertifikat Kepemilikan Bangunan Gedung (SKBG Serasun) yaitu kepemilikan atas sarusun diatas barang milik negara / daerah berupa tanah atau tanah wakaf dapat dijadikan jaminan kredit dengan dibebani fidusia.

Berdasarkan ketentuan pasal 27 UndangUndang Hak Tanggungan ${ }^{23}$ nyatakan bahwa "ketentuan undang-undang ini berlaku juga terhadap pembebanan hak jaminan atas Rumah Susun dan Hak Milik atas Satuan Rumah

${ }^{22}$ Mariam Darusbadrulzaman, 1983, Perjanjian Kredit Bank, Alumni, Bandung, hal.4

${ }^{23}$ Undang-Undang Nomor 4 Tahun 1996 tetang Hak Tanggungan atas Tanah beserta Benda-Benda yang Berkaitan dengan Tanah, Pasal 27 
Susun". Atas dasar ketentuan ini maka satuan kondotel dapat dijadikan jaminan kredit dimana dalam hal ini yang menjadi obyek jaminan kredit dan diikat dengan Hak Tanggungan adalah hak milik atas satuan kondotel beserta bagian bersama, benda bersama sebesar bagian pemilik hak milik atas satuan kondotel.

Terhadap kondotel yang dibebani dengan jaminan fidusia oleh karena bukti kepemilikannya berupa sertifikat kepemilikan bangunan Gedung (SKBG Sarusun). Menurut ketentuan pasal 1 ayat (1) Undang-Undang Jaminan fidusia20 menyatakan bahwa fidusia adalah pengalihan hak kepemilikan suatu benda atas dasar kepercayaan dengan ketentuan bahwa benda yang kepemilikannya dialihkan tersebut tetap dalam penguasaan pemilik benda. Jaminan fidusia adalah hak jaminan atas benda bergerak baik yang berwujud maupun yang tidak berwujud dan benda tidak bergerak khususnya bangunan yang tidak dapat dibebani hak tanggungan sebagaimana dimaksud dalam Undang-Undang Nomor 4 Tahun 1996 tentang Hak Tanggungan yang tetap berada dalam pengusaan pemberi fidusia sebagai agunan bagi pelunasan hutang tertentu yang memberikan kedudukan yang diutamakan kepada penerima fidusia terhadap kreditur lainnya (ayat 2).

Notaris berdasarkan kewenangannya dapat memberikan pemahaman kepada kliennya sebelum menandatangani perjanjian bahwa masing-masing pihak akan menjunjung asas itikad baik dalam pelaksanaan perjanjian yang dibuat. Dalam hal obyek yang belum ada maka perjanjian pendahuluan tentang jual beli kondotel dilakukan secara dibawah tangan, untuk selanjutnya perjanjian tersebut dilegalisasi oleh notaris agar setidaknya para pihak tidak dapat memungkiri tanda tangan yang dibubuhkannya dalam perjanjian tersebut, sehingga pelaksanaan perjanjian telah memenuhi prinsip-prinsip hukum sebagaimana diatur dalam ketentuan Pasal 1338 KUHPerdata yaitu perjanjian harus dilaksanakan dengan itikad baik.

Dengan demikian hal-hal penting yang harus menjadi perhatian dalam transaksi kondotel adalah sebagai berikut:

- Dalam melakukan perbuatan hukum jual beli sarusun yang berada di atas tanah yang masih dibebankan hak tanggungan atau kondotel belum selesai dibangun, maka dapat dilaksankan dengan perjanjian pendahuluan tentang jual beli sarusun secara dibawah tangan yang mendapat legalisasi dari notaris;

- Perjanjian pendahuluan yang dibuat dibawah tangan tersebut tetap mengindahkan asas-asas pokok hukum kontrak yakni asas kebebasan berkontrak, asas konsensualitas,

asas

proporsionalitas, asas kekuatan mengikatnya perjanjian, dan asas itikad baik, sehingga kelemahankelemahan dari perjanjian pendahuluan secara dibawah tangan tidak akan dimanfaatkan oleh salah satu pihak untuk mengambil keuntungan sendiri dengan merugikan orang lain.

Menurut Adrian Sutedi ${ }^{24}$ kondominium adalah bentuk hak guna perumahan dimana suatu bagian tertentu dimiliki secara pribadi sementara penggunaan lain dan akses ke fasilitas umum berada dibawah hukum yang dihubungkan dengan kepemilikan pribadi dan dikontrol oleh asosiasi pemilik. Adrian Sutedi juga menjelaskan strata title adalah terminologi barat popular tentang suatu kepemilikan terhadap sebagian ruang dalam suatu gedung bertingkat seperti apartemen atau rumah susun.

Dalam hukum di Indonesia sesuai UU Rumah Susun, pengertian kondominium sama dengan rumah susun sedangkan pengertian strata title sama dengan sarusun. Hal tersebut dapat dilihat pada Pasal 1 angka 1 dan angka 3 UU Rumah Susun yaitu:

- Pasal 1 angka 1 bahwa Rumah susun adalah bangunan gedung bertingkat yang dibangun dalam suatu lingkungan yang terbagi dalam bagian-bagian yang distrukturkan secara fungsional, baik dalam arah horizontal maupun vertikal dan merupakan satuan-satuan yang masing-masing dapat dimiliki dan digunakan secara terpisah, terutama untuk tempat human yang dilengkapi dengan bagian bersama, benda bersama, dan tanah bersama. Berdasarkan ketentuan tersebut konsep kondominium atau kondotel sebagaimana dijelaskan di atas mengarah kepada bangunan-bangunan yang bagianbagian atau ruang-ruang tertentu dapat dimiliki secara pribadi, sehingga hal tersebut sama dengan pengertian rumah susun pada UU Rumah Susun, sehingga kondominium ataupun kondotel dapat dipersamakan dengan rumah susun .

- Pasal 1 angka 3, Satuan rumah susun yang selanjutnya disebut sarusun adalah unit rumah susun yang tujuan utamanya digunakan secara terpisah dengan fungsi

${ }^{24}$ Adrian Sutedi, 2010, Hukum Rumah Susun dan Apartemen, Sinar Grafika, Jakarta, hal. 138, 
utama sebagai tempat hunian dan mempunyai sarana penghubung ke jalan umum.

Pendapat Soedikno Mertokusumo ${ }^{25}$ terkait konsep tanah bersama memaparkan bahwa hukum agrarian adalah keseluruhan kaidahkaidah hukum, baik yang tertulis maupun yang tidak tertulis yang mengatur agraria. Dari pendapat tersebut dapat diperjelas dengan penambahan yakni hukum agraria adalah keseluruhan peraturan-peraturan hukum baik yang tertulis maupun tidak tertulis yang semuanya mempunyai obyek pengaturan yang sama yaitu hak penguasaan atas tanah sebagai lembaga-lembaga hukum dan sebagai hubungan hukum yang konkret beraspek publik dan privat yang dapat disusun secara sistematis hingga keseluruhannya menjadi satu kesatuan yang merupakan satu sistem.

Dalam hukum agraria, tanah dalam pengertian yuridis menurut UUPA yaitu disebut hak. Jadi dalam hal ini hukum tanah tidak mengatur tanah dari segala aspek namun hanya mengatur salah satu aspek yuridisnya yang disebut dengan hak-hak penguasaan tanah.Ketentuan $\neg$ ketentuan hukum yang mengatur hak-hak penguasaan atas tanah dapat disusun menjadi satu kesatuan yang merupakan satu sistem yang disebut dengan hukum tanah.

Selain tanah, bangunan merupakan benda yang berada di atas tanah juga penting bagi kehidupan manusia. Bahkan bangunan membuat manusia membangun berbagai macam bangunan untuk memenuhi kebutuhannya. Perkembangan teknologi konstruksi dan rancang bangun membuat manusia dapat membangun bangunan sesuai dengan keinginannya baik secara horizontal, vertikal maupun didalam tanah. Bangunan merupakan suatu benda yang terdiri atas ruang dalam pengertian yuridis yang terbatas, memiliki ukuran tiga dimensi yaitu panjang, lebar dan tinggi. Sedangkan terhadap hak atas tanah, hak atas sebagian tertentu permukaan bumi yang terbatas berdimensi dua dengan ukuran panjang dan lebar.

Menurut Marihot P. Siahaan sebagaimana dikutip oleh Suhariningsih ${ }^{26}$ konsep tanah bersama, bangunan menjadi benda tidak bergerak karena disatukan dengan tanah tempat bangunan tersebut didirikan. Pendapat tersebut merupakan penerapan asas accesie atau asas perlekatan sebagaimana pendapat Boedi Harsono terkait konsep tanah bersama

${ }^{25}$ Soedikno Mertokusumo, 1996, Eksekusi Obyek Hak Tanggungan Permasalahan Dan Hambatan, Makalah Disajikan Pada Penataran Dosen Hukum Perdata Diselenggarakan Oleh Fakultas Hukum UGM, Yogyakarta, Juli 1996

26 Suhariningsih, 2009, Tanah Terlantar, Asas dan Pembaharuan Konsep Menuju Penertiban, Prestasi Pustaka Publiser, Jakarta, hal.55 menyatakan bahwa bangunan-bangunan dan benda $\neg$ benda/tanaman yang terdapat di atasnya merupakan satu kesatuan tanah,serta merupakan bagian dari tanah yang bersangkutan. Dengan demikian bangunan merupakan benda yang penting bagi kehidupan manusia yang selalu dikaitkan dengan tanah.

Menurut Imam Kuswahyono ${ }^{27}$ pertelaan dalam SHMSRS, sistem pemilikan atas suatu gedung bertingkat dapat dibagi menjadi 2 (dua) di atas, maka UURS 20/2011 telah merumuskan jenis kepemilikan perorangan dan pemilikan bersama satu kesatuan jenis pemilikan yang baru yang disebut Hak Milik atas Satuan Rumah Susun. Dengan demikian kepemilikan hak atas tanah pada satuan kondotel dalam kerangka hukum benda mengacu kepada sistem sebagaimana yang diatur dalam buku II KUHPerdata, dimana terdapat pemilikan individual atas satuan kondotel yang merupakan hak penghuni atau pemilik, disamping itu terdapat hak kepemilikan bersama atas tanah dimana bangunan tersebut terletak dan hak milik bersama atas sarana-sarana bangunan.

Hubungan hukum atara orang atau badan hukum dengan tanah merupakan hubungan perdata, artinya kewenangan orang atau badan hukum untuk berbuat sesuatu atas tanah tersebut sebatas hak yang diberikan oleh negara sebagaimana diatur dalam UUPA. Jadi orang atau badan hukum sebagai pemegang hak tidak boleh melakukan hal-hal yang di luar haknya.

Terhadap kondotel berlaku juga ketentuan tersebut karena dalam Undang-Undang Rumah Susun dinyatakan bahwa pemilik sarusun adalah subyek yang memenuhi syarat sebagai pemegang hak atas tanah bersama, meskipun kondotel hanya bangunan atau ruangan dalam pemilikannya tidak terlepas dari tanahnya, hubungan hukum antara pemilik satuan kondotel dengan kondotel yang bersangkutan juga meliputi, hubungan hukum pemilik dengan tanah bersama.

Hak milik merupakan hak yang terpenuh dan paling kuat serta bersifat turun-temurun, yang hanya dapat diberikan kepada warga negara Indonesia secara perorangan sesuai Pasal 20 dan 21 UUPA.Hak milik menurut John Locke mengatakan bahwa "Kerja" tubuhnya dan "karya" tangannya adalah sesuatu yang khas miliknya.Maka teori hak milik pribadi oleh John Locke dapat dianalisis dan diterapkan pada kepemilikan SHMSRS. Oleh karena untuk mendapatkan suatu hak milik pribadi, seseorang harus melakukannya dengan bekerja dan berkarya. Bekerja dan berkarya dalam arti mengurus segala proses agar mendapatkan suatu hak milik secara pribadi, termasuk bekerja untuk mencari uang sehingga mendapatkan hak milik pribadi. Seseorang dengan memiliki hak milik

27 Imam Kuswahyono, 2004, Hukum Rumah Susun: Suatu Bekal Pengantar, Pemahaman, Banyumedia, Malang, hal. 14 
pribadi maka ia dapat menguasai hak tersebut secara individu tanpa campur tangan pihak lain.

Hak milik tersebut berbeda dengan hak milik atas satuan rumah susun.Walaupun istilah yang digunakan juga hak milik, namun hak milik atas satuan rumah susun tidaklah merupakan hak terpenuh atau yang paling kuat sebagaimana hak milik, hak milik atas satuan rumah susun tidaklah menjadi hak milik pribadi secara sempurna. Walaupun ada hak-hak yang dikuasai secara pribadi yakni suatu ruang dalam gedung, namun ada hak-hak bersama yakni hak atas tanah yaitu tempat bangunan rumah susun tersebut berada, bagian bersama yaitu segala bagian dari bangunan gedung yang melekat pada gedung rumah susun seperti lift, kolam renang, lobby, dan sebagainya, serta benda bersama yaitu benda-benda yang berada di area rumah susun yang tidak melekat pada gedung misalnya kursi-kursi di lobby, lukisan, dan lain sebagainya.

Hak milik atas satuan rumah susun yang berada di atas tanah Hak Guna Bangunan maupun Hak Pakai yang berdasarkan Pasal 25 Peraturan. Pemerintah Nomor 40 Tahun 1996 tentang Hak Guna Usaha, Hak Guna Bangunan dan Hak Pakai Atas Tanah (selanjutnya disebut PP 40/1996 tentang HGU, HGB, dan HP) jangka waktu maksimalnya adalah 30 (tiga puluh) tahun dan dapat diperpanjang maksimal 20 (dua puluh) tahun untuk HGB, sedangkan untuk Hak Pakai diberikan maksimal dengan jangka waktu 25 (dua puluh lima) tahun dan dapat diperbaharui kembali. Sehingga hak milik atas satuan rumah susun akan berakhir apabila jangka waktu HGB atau Hak Pakai juga telah berakhir. Dengan demikian maka selanjutnya perhimpunan pemilik dan penguhuni satuan rumah susun (selanjutnya disebut PPPSRS) jika ingin melanjutkan hak nya harus mengurus perpanjangan atau pembaharuan terhadap hak atas tanah bersama tersebut.

Pembebanan hak tanggungan merupakan langkah lanjutan dari perjanjian pinjam meminjam atau perjanjian kredit sebagaimana yang dikatakan oleh Mariam Darusbadrulzaman ${ }^{28} 30$ yakni perjanjian kredit tersebut adalah "Perjanjian Pendahuluan" (Voorovereenkomst), sehingga tidak ada hak tanggungan tanpa perjanjian kredit. Pada umumnya yang melakukan kegiatan penyaluran dana ke masyarakat melalui kredit adalah bank. Bank merupakan salah satu lembaga yang memegang peranan penting dalam perekonomian nasional. Dari segi fungsinya, bank merupakan perantara antara kepentingan masyarakat dibidang dana, yaitu kepentingan dari masyarakat yang berkelebihan dana dengan kepentingan dari masyarakat yang membutuhkan dana. Bank menghimpun dana dari masyarakat luas dengan menyalurkan

28 Mariam Darusbadrulzaman, 1983, Perjanjian Kredit Bank, Alumni, Bandung, hal.4 kembali kepada masyarakat melalui pemberian pinjaman atau kredit yang merupakan dua fungsi utama bank.

Pemberian hak tanggungan didahului oleh janji debitur untuk memberikan hak tanggungan kepada kreditur sebagai jaminan pelunasan utang.Janji tersebut dituangkan dan merupakan bagian tak terpisahkan dari perjanjian utang piutang, yang kemudian dilakukan pemberian hak tanggungan melalui pembuatan APHT. Berdasarkan pengalaman pra-magang yang penulis lakukan pada beberapa kantor notaris, dalam APHT wajib dicantumkan beberapa hal sebagai berikut:

1. Nama dan identitas pemegang dan pemberi hak;

2. Domisili para pihak yang tercantum dalam akta;

3. Penunjukan secara jelas utang yang dijaminkan dengan hak tanggungan;

4. Nilai tanggungan; dan

5. Uraian yang jelas mengenai objek hak tanggungan.

Di samping itu dalam APHT dapat pula dicantumkan adanya janji-janji, kecuali untuk memiliki objek hak tanggungan. Isi janji janji tersebut adalah:

1. Membatasi kewenangan pemberi hak tanggungan untuk menyewakan objek hak tanggungan kecuali persetujuan tertulis pemegang hak;

2. Membatasi kewenangan pemberi hak tanggungan untuk mengubah bentuk atau susunan objek hak, kecuali dengan persetujuan tertulis pemegang hak;

3. Memberikan kewenangan kepada pemegang hak tanggungan untuk mengelola objek hak berdasarkan penetapan Ketua Pengadilan Negeri;

4. Memberikan kewenangan kepada pemegang hak tanggungan untuk menyelamatkan objek hak jika diperlukan untuk pelaksanaan eksekusi atau untuk mencegah hapusnya atau dibatalkannya hak yang menjadi objek hak tanggungan karena tidak dipenuhi atau dilanggarnya ketentuan undang $\neg$ undang;

5. Pemegang hak tanggungan pertama berhak menjual atas kekuasaan sendiri;

6. Pemegang hak tanggungan tidak akan melepaskan hak dan tanahnya;

7. Janji pemegang hak tanggungan untuk memperoleh seluruh atau sebagian ganti rugi jika hak atas 
tanah yang menjadi objek hak tanggungan dicabut atau dialihkan;

8. Janji Pemegang Hak Tanggungan untuk mengosongkan obyek hak pada waktu eksekusi hak tanggungan

APHT tersebut dibuat oleh PPAT sesuai fungsi PPAT menurut UUHT adalah sebagai pejabat untuk membuatAPHT. Setelah APHT dibuat maka PPAT wajib menyerahkan salah satu salinannya disertai warkah lain yang diperlukan kepada Kantor Pertanahan sesuai Pasal 10 ayat 2 dan 13 ayat 2 UUHT.

Dari janji janji dalam APHT yang disebutkan di atas, tentunya masih dapat ditambahkan sesuai kesepakatan para pihak. Dalam hal yang menjadi obyek hak tanggungan adalah hak atas tanah yang akan dibangun rumah susun, maka dapat diperjanjikan pula suatu janji janji yang akan dilakukan dikemudian hari selama pembebanan hak tanggungan tersebut, antara lain:

1. Penerima hak tartggungan telah mengetahui perunhakan obyek hak tangguan akan dibangun rumah susun;

2. Penerima hak tanggungan bersedia membantu hal-hal yang diperlukan dalam pengurusan pendaftaran hak milik atas satuan rumah susun tanpa melepaskan hak tanggungan yang diberikan oleh pemberi hak tanggunan;

3. Penerima hak tanggungan bersedia memindahkan hak tanggungan yang semula pada tanah ke sarusun-sarusun ketika SHMSRS sudah diterbitkan oleh kantor pertanahan setempat;

4. Penerima hak tanggungan bersedia melakukan roya partial terhadap salah satu sarusun yang akan dijual setelah dilunasinya sebagian utang pemberi hak tanggungan, yang nilainya telah diperhitungkan senilai dengan harga sarusun.

Dengan didahuluinya perjanjian APHT dengan janji-janji yang isinya seperti tersebut di atas maka berdasarkan analisa penulis meyakini bahwa pembeli sarusun mendapatkan perlindungan hukum terkait SHMSRS miliknya.Selain itu bank selaku kreditor juga terlindungi hak nya sebagai pemegang hak tanggungan. Pengembang atau penyelenggara rumah susun juga bebas dari tuntutan pihak lain. Prosedur penjaminan tanah bersama pada rumah susun tersebut hanyalah penjaminan terhadap satuan kondotel mengacu pada hak tanggungan, sehingga untuk saat ini tidak ada suatu aturan yang mengatur mengenai prosedur pembebanan hak atas tanah bersama sebagai jaminan kredit kredit bank terhadap rumah susun khususnya kondotel.

\section{KESIMPULAN}

1. Pengaturan kondominium hotel sebagai obyek hak tanggungan dalam perjanjian kredit bank dapat diklasifikasikan kedalam tiga stuktur norma pengaturan yang terdiri dari:

1) Norma pengaturan yang bersifat umum, yang mendasarkan pengaturan pada ketentuanketentuan hukum peraturan perundang-undangan terkait dengan perbankan, pengadaan rumah susun dan hak tanggungan

2) Norma pengaturan yang bersifat khusus yang meliputi ketentuan prinsip kehati-hatian dalam pemberian kredit, ketentuan mengenai analisa mendalam terhadap karakter, kapital, kolateral dan kapasitas debitur serta ketentuan batas maksimum pemberian kredit dari bank selaku kreditur.

3) Norma pengaturan konstruktif berupa model kontrak yang disepakati oleh pihak-pihak dalam pemberian kredit dengan obyek kondominium hotel melalui hak tanggungan, yang berlaku sebagai undang-undang bagi para pihak yang membuatnya

2. Perlindungan hukum terhadap pemilik satuan kondominium hotel apabila terjadi wan prestasi dalam perjanjian kredit bank adalah dengan mengupayakan prinsip itikad baik (good faith) baik pada awal perjanjian, pelaksanaan perjanjian hingga berakhirnya perjanjian dengan menegaskan pada substansi perjanjian tentang konstruksi hukum kondominium hotel dengan adanya karakteristik yang melekat pada kondominium hotel yaitu adanya tanah bersama dan benda bersama. Perlindungan hukum dalam hal terjadi wan prestasi adalah dengan adanya ketegasan pemisahan dari kepemilikan terhadap satuan kondotel dengan tanah bersama dan benda bersama yang menjadi obyek hak tanggungan. 


\section{DAFTAR PUSTAKA}

Abdulkadir Muhammad, 2004, Hukum dan Penelitian Hukum, PT Citra Aditya Bakti,Bandung

Adrian Sutedi, 2010, Hukum Rumah Susun dan Apartemen, Sinar Grafika, Jakarta

Boedi Harsono, Edisi 2008, Hukum Agaria Indonesia, Djambatan, Jakarta

Hans Kelsen, 2006, General Theory of Law and States (Teori Umum Tentang Negara dan Hukum), Penerjemah Raisul Multaqien, Bandung: Nusa Media \& Nuansa.

I Made Pasek Diantha, 2016, Metodologi Penelitian Hukum Normatif dalam justifikasi Teori Hukum, Prenada Media Group, Jakarta

Imam Kuswahyono, 2004, Hukum Rumah Susun: Suatu Bekal Pengantar, Pemahaman, Banyumedia, Malang

John Rawls,1995, A Theory Of Justice, Harvard university press, Massachusetts terjemahan oleh Unzair Fauzan dan Heru Prasetyo, 2006, Teori Keadilan, Dasar-dasar Filsafat Politik untuk Mewujudkan Kesejahteraan Sosial dalam Negara, Pustaka Pelajar, Yogyakarta

M. Bahsan, 2007, Hukum Jaminan Dan Jaminan Kredit Perbankan Indonesia, PT. Raja Grasindo Persada, Jakarta

Maria Farida Indrawati Soeprapto, 1996, Ilmu Perundang-undangan, Kanisius, Yogyakarta.

Mariam Darusbadrulzaman, 1983, Perjanjian Kredit Bank, Alumni, Bandung

Parikesit D. dan Trisandi,1997, Kebijakan Kepariwisataan Indonesia Dalam Pembangunan Jangka Panjang, Jogyakarta, Gajahmada University Business Review No. 16/VI hal.67

Peter Mahmud Marzuki, 2013, Penelitian Hukum, Kencana, Jakarta

Philipus M. Hadjon, 2007, Perlindungan Hukum Bagi Rakyat di Indonesia, Peradaban, Surabaya

Rachmadi Usman, 2001, Aspek-Aspek Hukum Perbankan di Indonesia, PT Gramedia Pustaka Utama, Jakarta.

Satjipto Raharjo, 2000, Ilmu Hukum, PT Citra Aditya Bakti, Bandung

Soedikno Mertokusumo, 1996, Eksekusi Obyek Hak Tanggungan Permasalahan Dan Hambatan, Makalah Disajikan Pada Penataran Dosen Hukum Perdata Diselenggarakan Oleh Fakultas Hukum UGM, Yogyakarta, Juli 1996

Kitab Undang-undang Hukum Perdata

Undang-Undang Nomor 5 Tahun 1960 tentang Peraturan Dasar Pokok-Pokok Agraria. ( Lembaran Negara Republik Indonesia Tahun 1960 Nomor 104)

Undang-Undang Nomor 25 Tahun 2007 tentang Penanaman Modal.

( Lembaran Negara Republik Indonesia Tahun 2007 Nomor67)

Undang-Undang Nomor 40 Tahun 2007 tentang Perseroan Terbatas

( Lembaran Negara Republik Indonesia Tahun 2007 Nomor 106)

Undang-Undang No. 10 Tahun 2009 Tentang Kepariwisataan

( Lembaran Negara Republik Indonesia Tahun 2009 Nomor 11)

Undang-Undang Nomor 20 Tahun 2011 Tentang Rumah Susun

( Lembaran Negara Republik Indonesia Tahun 2011 Nomor 108) 